\title{
Mouth-gaping Behavior in the Bell Glass Frog, Cochranella nola (Anura: Centrolenidae) in Southeastern Peru
}

Cristina Arrivillaga

Crees Foundation. Fundo Mascoitania, Manu, Madre de Dios, Perú (cristinaarrivillaga@gmail.com)

$\mathrm{T}$ he Bell Glass Frog (Cochranella nola), like other species in the family Centrolenidae, is arboreal and occurs almost exclusively in riparian vegetation at high elevations (Villacampa et al. 2017). This species was thought to be endemic to Bolivia until 2013 when it was found in the Amazonian foothills of the Puno Region in southeastern Peru (Lujan et al. 2014) and later reported in the Manu Biosphere Reserve by Villacampa et al. (2017). The Bell Glass Frog is classified as Near Threatened on the IUCN Red List (Cortéz et al. 2004) due to its habitat seemingly declining in both quantity and quality (Lujan et al. 2014). Herein we report the first observation of Cochranella nola displaying mouth-gaping behavior.

At $2237 \mathrm{~h}$ on 11 April 2019, an adult was found on a leaf $70 \mathrm{~cm}$ above the ground in secondary forest $\left(-12.802573^{\circ} \mathrm{S}\right.$, $-71.403664^{\circ} \mathrm{W}$; WGS 84; elev. $525 \mathrm{~m}$ asl) at the Manu Learning Center Reserve (MLC) and taken to the MLC facilities. The MLC is a research station owned and operated by the Crees Foundation and located within 643 ha of secondary lowland tropical forest in the cultural zone of the Manu Biosphere Reserve in southeastern Peru. The next morning the frog was placed in a glass terrarium, where later that day, at approximately $1650 \mathrm{~h}$, I confirmed its identity. Roughly 10 min after the examination, at $1703 \mathrm{~h}$, the frog began exhibiting mouth-gaping behavior. The entire display lasted about 2 min after it was first noticed.
As described by Folly et al. (2019), each mouth-gaping event (duration 1-13 sec) consisted of three phases: mouth closed, mouth completely open, and mouth partially open (Fig. 1). The individual remained in place and in the same position and engaged in no additional behaviors. Because this behavior is known to be utilized as a defensive strategy (Toledo et al. 2011), the display was likely induced by my handling of the individual, causing it to behave as if it were being attacked.

Previously reported glass-frog defenses include cloacal discharge of odoriferous secretions, crouching down, and elevation of and puffing up the body (Escobar-Llasso and RojasMorales 2012); noxious secretions (Rueda-Almonacid 1994); biting during parental care (Drake and Ranvestel 2005); and death feigning (Toledo et al. 2010). Mouth-gaping in centrolenids has been reported only once by Barbosa (2015), yet it has been widely documented in several species of anurans (Toledo et al. 2011). This visual display attracts a predator's attention, intimidates it, and hinders the sequence of attack, therefore aiding the frog to avoid subjugation (Toledo et al. 2011).

Aside from a few cases, Toledo et al. (2011) state that mouth gaping usually is accompanied by defensive vocalizations. However, the individual in this observation did not emit any sounds during the opening and closing of its mouth. Toledo and Haddad (2009) provided a possible explanation
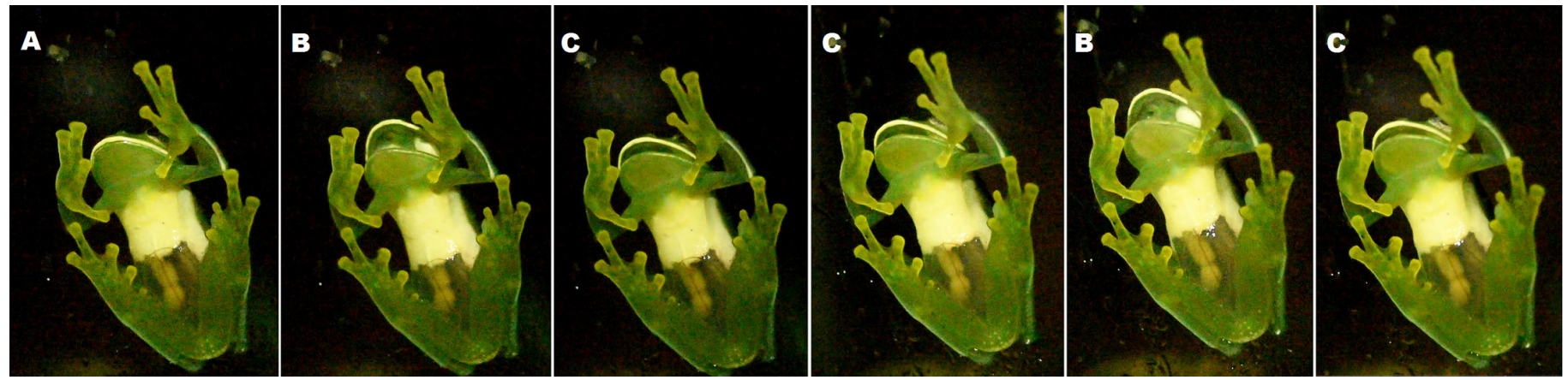

Fig. 1. Stop-motion images taken from a 0.6-sec video showing an adult Bell Glass Frog (Cochranella nola) displaying mouth-gaping behavior: (A) Mouth closed, (B) mouth fully open, and (C) mouth partially open. Video by Cristina Arrivillaga.

Copyright (C) 2019. Cristina Arrivillaga. All rights reserved. 
when they found a positive relationship between the duration of anuran distress calls and snout-to-vent length, indicating that only larger frogs produce defensive vocalizations that are long and loud enough to be successful against predators. Consequently, C. nola might have to rely on defensive strategies other than agonistic calls due to its small size (SVL 22.1-30.1 mm; Villacampa et al. 2017) resulting in ineffectual calls insufficient for deterring a predator (Folly et al. 2019). Toledo et al. (2011) also suggested that this behavior originated in species that shrieked defensively, with smaller descendants losing that ability while retaining the mouthopening behavior.

Because mouth-gaping has only been reported once previously in glass frogs (Barbosa 2015), I suggest that this behavior is probably unusual and therefore rarely documented in centrolenids.

\section{Acknowledgements}

I thank The Crees Foundation and its director, Quinn Meyer, for providing the opportunity to participate in their long-term herpetological monitoring programme at the Manu Learning Centre. Special thanks to conservation interns Stefan Barton and Carlo André Márquez for finding the frog that led to this observation and bringing it to the MLC facilities.

\section{Literature Cited}

Barbosa, R. 2015. Ecology, Behavior and Taxonomy of Anurans from Brazil's Atlantic Forest. Unpublished Ph.D. Dissertation, Utah State University. Logan, Utah.

Cortez, C., S. Reichle, I. de la Riva, and J. Köhler. 2004. Cochranella nola. IUCN Red List of Threatened Species 2004: e.T54973A11220213.

Drake, D.L. and A.W. Ranvestel. 2005. Hyalinobatrachium colymbiphyllum (Glass Frog). Egg mass defense. Herpetological Review 36: 434.

Escobar-Llasso, S. and J.A. Rojas-Morales. 2012. Antipredatory behaviors of the Colombian endemic glassfrog Centrolene savagei (Anura: Centrolenidae). Boletín Cientifico Centro de Museos, Museo de Historia Natural 16: 226-232.

Folly, H., G.A. Sestito, E. Almeida Pereira, J. Ferrari Morais, D.J. Santana, and R. Neves Feio. 2019. Defensive behavior of Ololygon carnevallii Caramaschi \& Kisteumacher, 1989 (Anura: Hylidae). Herpetozoa 31: 195-200.

Lujan, L., P.J. Venegas, and L.Y. Echeverría. 2014. Cochranella nola Harvey, 1996 (Amphibia, Anura, Centrolenidae): First country record from Peru. Herpetology Notes 7: 607-608.

Rueda-Almonacid, J.V. 1994. Estudio anatómico y relaciones sistemáticas de Centrolene geckoideum (Salentia: Anura: Centrolenidae). Trianea 5: 133-187.

Toledo, L.F. and C.F.B. Haddad. 2009. Defensive vocalizations of Neotropical anurans. South American Journal of Herpetology 4: 25-42.

Toledo, L.F., I. Sazima, and C.F.B. Haddad. 2010. Is it all death feigning? Case in anurans. Journal of Natural History 44: 31-32.

Toledo, L.F., I. Sazima, and C.F.B. Haddad. 2011. Behavioural defences of anurans: an overview. Ethology, Ecology \& Evolution 23: 1-25.

Villacampa, J., S. Serrano-Rojas, and A. Withworth. 2017. Amphibians of the Manu Learning Centre and Other Areas of the Manu Region. The Crees Foundation, Cusco, Peru.

Vockenhuber, E. A., Hödl, W. \& Karpfen, U. 2008. Reproductive behaviour of the glass frog Hyalinobatrachium valerioi (Anura: Centrolenidae) at the tropical stream Quebrada Negra (La Gamba, Costa Rica). Stapfia 88, zugleich Kataloge der oberösterreichischen Landesmuseen Neue Serie 80: 335-348 